\title{
SIMULATION-AIDED INVESTIGATION OF THE EFFECT OF A PRE-FORMING PROCESS ON THE INITIATION OF CRACKS, THE REQUIRED FORGING FORCES AND MATERIAL FLOWLINES FOR MINING GROUND SUPPORT CLAMPS' MANUFACTURE USING THE HOT-FORGING TECHNIQUE
}

\author{
S SIMULACIJO PODPRTA RAZISKAVA VPLIVA PROCESA \\ PREDOBLIKOVANJA NA NASTANEK RAZPOK, ZAHTEVANIH SIL \\ KOVANJA IN LINIJ TEČENJA PRI SPONAH RUDARSKIH PODPOR, \\ IZDELANIH Z VROČIM KOVANJEM
}

\author{
Ilter Kilerci ${ }^{1}$, Osman Culha ${ }^{2}$ \\ ${ }^{1}$ Manisa Celal Bayar University, Mechanical Engineering Department, Ilhan Varank Campus, 45140, Manisa, Turkey \\ ${ }^{2}$ Manisa Celal Bayar University, Metallurgical and Materials Engineering Department, Ilhan Varank Campus, 45140, Manisa, Turkey \\ ilter.kilerci@cbu.edu.tr \\ Prejem rokopisa - received: 2017-11-20; sprejem za objavo - accepted for publication: 2018-01-09
}

doi:10.17222/mit.2017.195

In this study, the influence of the number of forging stages on the crack formation and forging forces in the hot-forging process for mining support clamps that were produced from 31Mn4 material was investigated. In this context, a single-stage process has been considered and a multiple-stage forging process that included a pre-forming stage was fictionalized with the aim of preventing crack formation by obtaining crack-formation zones. It is aimed to improve the toughness properties of the final product by ensuring that the material flow lines are obtained in accordance with the product geometry as well as preventing the formation of cracks by the forging process design, including the preforming step of the mining support clamp. Designed dies and workpieces were simulated using the finite-volume method. According to the simulation results of forging process, the stress and strain variation of materials is obtained as max. $229 \mathrm{MPa}$ and $3.969 \mathrm{MPa}$. Damage analysis of the sample with effective stress and strain is exposed as 0.438-1.0 flash surface of material. The increase in the forming step decreased the forging forces per step and the crack formation was prevented and the material flowlines can be arranged in accordance with the product geometry in the presence of the preforming stage in the hot-forging process and that this regulation has a reducing effect on the forging forces. The material flowlines of the samples obtained from real production were examined and validation of the simulations and actual production was provided.

Keywords: Toussaint-Heintzmann mining support clamp, hot forging, pre-forming, Cockroft-Latham simulation

Avtorji v prispevku opisujejo študijo vpliva števila stopenj kovanja na nastanek razpok ter sil pri procesu vročega kovanja med izdelavo spon rudarskih podpor, izdelanih iz jekla 31Mn4. Raziskovali so enostopenjski in večstopenjski proces kovanja. V drugem primeru so izvedli namišljeno predoblikovanje $\mathrm{z}$ namenom preprečevanja nastanka razpok v conah preoblikovanja. Namen naloge je bil izboljšati žilavost končnega izdelka z zagotavljanjem ustreznih linij tečenja v skladu z geometrijo izdelka, kakor tudi preprečevanje nastanka razpok med oblikovanjem v procesu kovanja, vključno s fazo predoblikovanja spon rudarskih podpor. Simulacije dizajna orodij in odkovkov so izvedli z metodo končnih volumnov. Rezultati simulacij procesa kovanja so podali variiranje napetosti in deformacij z maksimalnimi vrednostmi $229 \mathrm{MPa}$ oz. 3,969 MPa. Analiza poškodb vzorca pri efektivnih napetosti in deformacijah $0,438-1,0$ se je pokazala kot bleščeča površina materiala. Povečanje števila stopenj oblikovanja je zmanjšalo možnosti za nastanek razpok in linije tečenja materiala so potekale $\mathrm{v}$ skladu z geometrijo izdelka, kar je tudi zmanjšalo sile kovanja. Linije tečenja materiala so avtorji prispevka preverili tudi na vzorcih $\mathrm{v}$ pogojih dejanske proizvodnje in jih ocenili oz. primerjali z rezultati simulacij.

Ključne besede: Toussaint-Heintzmannove spone rudarskih podpor, vroče kovanje, predoblikovanje, Cockroft-Lathamova simulacija

\section{INTRODUCTION}

The magnitude of the investment capital in mining activities is important thanks to the properties of increasing employment and providing raw material for the industrial sectors. ${ }^{1}$ Underground mining is a sector in which the studies based on reliability and productivity are conducted by mainly the mining engineering and other engineering disciplines due to the fact that it is the most risky profession in the world. The difficulty of the underground conditions requires a technical and syste- matical work, investment and organization for the mining activities to be able to be carried out. ${ }^{2-4} \mathrm{~A}$ significant part of the fatal accidents occurring in mining happens due to the fall of materials such as stone-coal and the collapses occurring in a direct or indirect way and this condition directly shows the importance of ground supports. It is absolutely necessary that the ground-support systems are used for the underground orifices to have long-life span and to allow working in a safe way during its service life. ${ }^{5}$ 
Forging is defined as the metal-forming method in which the workpiece is placed between the dies and the desired product shape is given under the pressing forces. ${ }^{6,7}$ Hammers and presses are used during the forging process. The forging processes are used for the purpose of giving outstanding mechanical properties to the piece to be produced and realizing the production with a minimum rate of waste. The process starts with the workpieces having a basic geometry compared to the final product. The workpiece is subjected to plastic deformation in one or more operations and pieces with complex shapes are attained. While the forging processes give superior mechanical properties to the materials, compared to other production methods, some manufacturing defects could be observed as a result of the incorrect mounting of the forging process design. ${ }^{6}$

The forging process is the most popular method in metal forming. A significant part of the industrial pieces are produced by forging thanks to their conformity to mass production and the ability to give superior mechanical properties. The parameters such as temperature, raw-material geometry and die designs are efficient in increasing the quality of the products and decreasing the manufacturing costs. ${ }^{7}$ The process of forming the geometry of a workpiece having a shape close to the final product geometry in hot forging is called as pre-forming. While the pre-forming process ensures a reduction in the material waste depending on the flash formation and the significant decrease in the machining processes, it decreases the die stress. ${ }^{8}$ The performance of the designs of the pieces that is planned to produce with forging according to trial and error causes a great loss of time and manufacturing costs. The foreseeing of the material flow is only possible with computer-aided simulations. ${ }^{7}$

An important issue in metal shaping is being able to carry out the desired deformation without causing damage to the workpiece. Although the materials are formed without any crack with the empirical experiences of the designers in the industrial applications, sometimes high-cost trial and error productions are needed. ${ }^{9}$ For this reason, foreseeing and preventing damage are the main properties in the forming process and the determination of the product quality. ${ }^{10}$

Today, new products and manufacturing methods are developed for the purpose of attainment as a result of low costs and short production processes. Although the design and optimization of the forming process are generally conducted by professionals having experience in the manufacturing operations, it is still obligatory for them to conduct trial and error. The use of numerical simulations for the purpose of avoiding this experimental procedure is an important tool for the improvement and development of the forming process. ${ }^{11,12}$

Most metal-forming methods are limited due to the internal or surface cracks of the workpiece..$^{10}$ Increasing the strength of the workpiece without any damage with plastic deformation is limited to formability. The formability of the materials are followed by the workability of that material. ${ }^{13}$ If the conditions causing the crack during the deformation of the workpiece could be foreseen; convenient process conditions could be selected, forming process could be changed and tough products could be obtained. ${ }^{14,15}$

In this study, the condition of real production in single or multiple stages by conducting the hot-forging simulations of the bottom-clamp component used in Toussaint-Heintzmann (TH) ground support systems with the infrastructure of finite volumes method has been examined within the direction of Cockroft Latham critical damage theory. Within the scope of the study, which has been conducted for the purpose of improving the surface, physical and mechanical properties of TH34 bottom-clamp which will be manufactured by the hot-forging processes and revealing the optimized sections; the process design, press selection, effect of raw material preparation, die design, final product geometry and the simulation of all the process and the material flow during the plastic deformation and the residual stress-strain distribution have been determined by examining the impact of temperature and the verification of the design has been ensured by pilot productions with the use of parameters attained as a result of the optimization works.

\section{EXPERIMENTAL PART}

The $31 \mathrm{Mn} 4$ steel is used in accordance with the DIN 21530-3 standard used for the final product within the scope of the study. ${ }^{16}$ The chemical composition of the steel is shown in Table $\mathbf{1}$.

Table 1: Chemical composition of 31Mn4 according to DIN 21530, in mass fractions $(w / \%)$

\begin{tabular}{|c|c|c|c|c|c|c|}
\hline $\mathrm{C}$ & $\mathrm{Si}$ & $\mathrm{Mn}$ & $\begin{array}{c}\mathrm{P} \\
\text { (max.) }\end{array}$ & $\begin{array}{c}\mathrm{S} \\
\text { (max.) }\end{array}$ & $\begin{array}{c}\mathrm{Al} \\
\text { (min.) }\end{array}$ & $\mathrm{Cu}$ \\
\hline $0.28-036$ & $0.2-0.5$ & $0.8-1.1$ & 0.035 & 0.035 & 0.02 & 0.35 \\
\hline
\end{tabular}

The DIN 21530 standard that determines the structure and properties of the ground support systems that also includes the TH supports is the standard that regulates the issues related to the quality and safety of the mine pit supports in the underground mine pits. It could also be used for the ground support of the space areas under the ground having no relation with mining and it ensures the realization of the function of the mine-pit supports in accordance with the plan both in terms of safety and operation by taking the standards into consideration. The TH34 Bottom clamp has been modeled with the use of the Solidworks 2014 program according to the measurements in Table 2 within the direction of DIN 21530-2 standard and the image belonging to the attained design is shown in Figure 1a. ${ }^{17}$ 


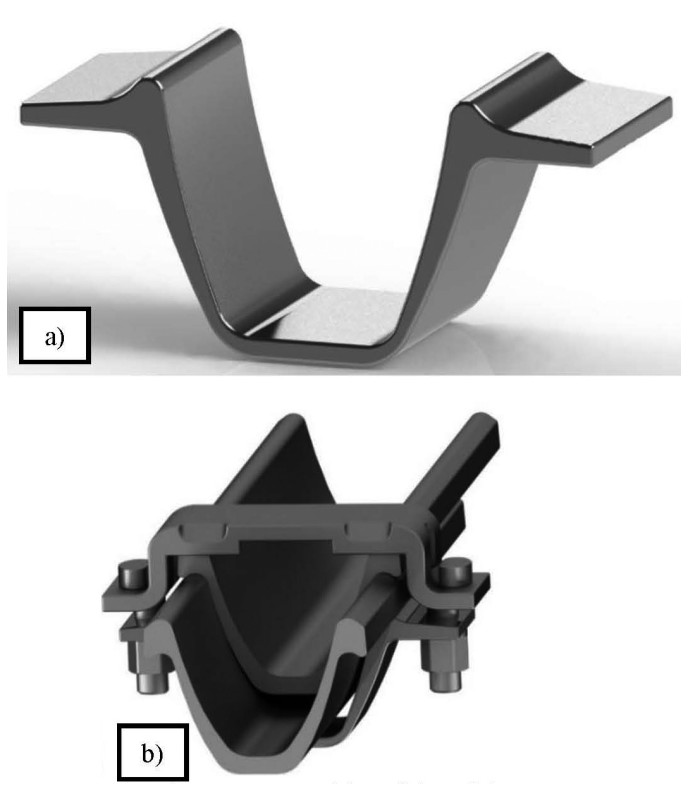

Figure 1: a) TH34 bottom clamp solid model, b) TH34 ground support assembly solid model

Table 2: TH34 Bottom Clamp Dimensions According to DIN 21530

\begin{tabular}{|c|c|c|c|c|c|}
\hline $\begin{array}{c}\text { Bottom } \\
\text { clamp }\end{array}$ & $\begin{array}{c}\text { Profile } \\
\text { class }\end{array}$ & $a(\mathrm{~mm})$ & $b(\mathrm{~mm})$ & $\begin{array}{c}c(\mathrm{~mm}) \\
\text { min. }\end{array}$ & $\varnothing d(\mathrm{~mm})$ \\
\hline $\mathrm{G} 400$ - G40 & 34 & $212_{0}^{+2}$ & $212_{-4}^{+1}$ & 111 & 30 \\
\hline
\end{tabular}

In Figure 1a following the design of the final stage of final product of TH34 bottom clamp has been dealt during the stage of the hot-forging process. The flash design of the forged piece was conducted by taking as the basis the equations developed by Voigtlander, Doege and Awiszus and the sections and forging dies belonging to all the other stages have been designed. ${ }^{18-20}$ Following the determination of the flash dimensions, a shrinkage allowance of $1.5 \%$ has been given to the final product geometry in the forging design of the final product for the purpose of meeting the volume changes of the

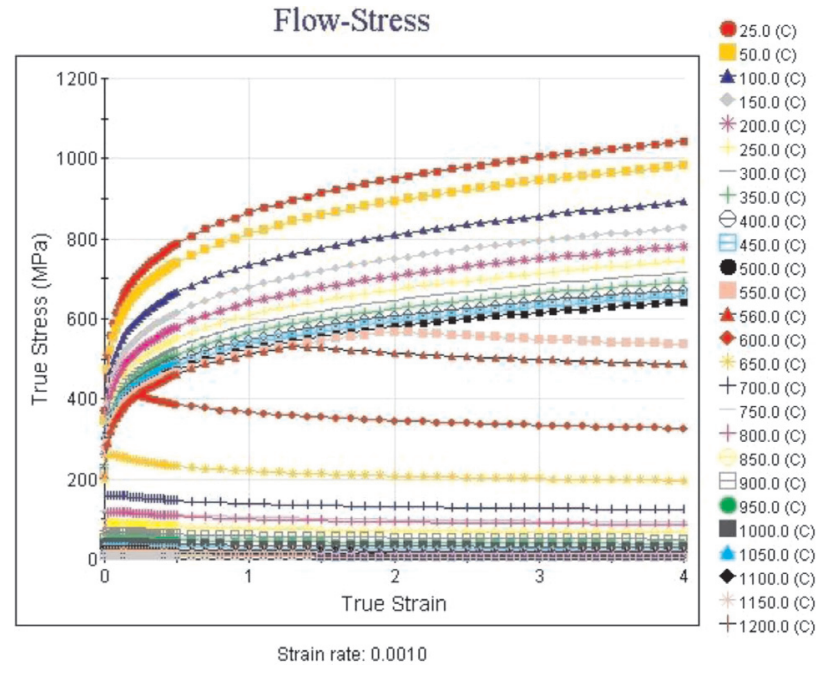

Figure 2: $31 \mathrm{Mn} 4$ material flow curves created in the JmatPro program

material during cooling. ${ }^{21,22}$ The sections and forging dies have been designed by taking the design principles of hot-forging dies. ${ }^{20-23}$

The 31Mn4 flow curves shown in Figure 2 by using $31 \mathrm{Mn} 4$ alloy properties as input in the JmatPro program environment have been attained for usage in simulation works. The $31 \mathrm{Mn} 4$ alloy formed in the computer environment has been integrated in Simufact forming program.

Hot-forging simulations of the TH34 bottom clamp used in Toussaint-Heintzmann ground supports within the scope of simulation activities and process optimization works have been carried out within the direction of the parameters shown in Table 3. ${ }^{24}$

Kang et al. and Han et al. analyzed the friction behavior by using the Coulomb friction model in the environment of FE simulations. ${ }^{7-9}$ However; because this model loses its validity in the event that the friction sliding stress increases the material shearing strength, its implementation area is limited. A constant sliding fric-

Table 3: Process parameters used in simulation studies

\begin{tabular}{|c|c|c|c|}
\hline \multicolumn{2}{|c|}{ Simulation 1 and 2} & \multicolumn{2}{|c|}{ Simulation 3} \\
\hline Number of stage & 1 & Number of stage & 3 \\
\hline Type of raw material & $31 \mathrm{Mn} 4$ & Type of raw material & $31 \mathrm{Mn} 4$ \\
\hline Raw material temperature & $1200{ }^{\circ} \mathrm{C}$ & Raw material temperature & $1200{ }^{\circ} \mathrm{C}$ \\
\hline Die temperature & $350{ }^{\circ} \mathrm{C}$ & Die temperature & $350^{\circ} \mathrm{C}$ \\
\hline Ambient temperature & $50{ }^{\circ} \mathrm{C}$ & Ambient temperature & $50{ }^{\circ} \mathrm{C}$ \\
\hline Friction factor & 0.1 & Friction factor & 0.1 \\
\hline Mesh type & Surface mesh & Mesh type & Surface mesh \\
\hline Mesh element type & Triangles & Mesh element type & Triangles \\
\hline Mesh element size & $2 \mathrm{~mm}$ & Mesh element size & $2 \mathrm{~mm}$ \\
\hline Mesh element count & & Mesh element count & \\
\hline Simulation 1 & 13748 & First pre-forming stage & 13748 \\
\hline Simulation 2 & 14086 & Second pre-forming stage & 36460 \\
\hline- & - & Finisher forging stage & 92378 \\
\hline Press Type and Tonnage & Friction press $1200 \mathrm{t}$ & Press type and tonnage & Friction press $1200 \mathrm{t}$ \\
\hline
\end{tabular}


tion model is frequently used in 3D FE simulations of the forging process. ${ }^{10-15}$

The deformation processes in the industrial applications were applied according to the experimentally determined ductile fracture criterion. Today, the Cockroft-Latham damage criterion has become convenient for the metal-forming simulations. Generally, the critical damage value is taken as equal to the flow limit of the material. However, Cockroft and Latham have not explained the issue of whether critical damage value is dependent on the temperature and strain rate. ${ }^{5,9}$ By using the Cockroft-Latham criteria, the fracture formation risk of the formed piece could be examined.

Cockroft and Latham have developed the accumulated damage theory in which variable loading conditions could be successfully applied. ${ }^{12-14}$ As a result of many studies conducted by Cockroft and Latham, they have examined the change between the applied equivalent strain and the effective stress $(\sigma)$ of the maximum tensile strength $\left(\sigma_{\mathrm{T}}\right)$ of the damage in plastic deformation, in Equation (1):

$$
C=\int_{0}^{\bar{\varepsilon}_{\mathrm{f}}} \frac{\sigma_{\mathrm{T}}}{\bar{\sigma}} \mathrm{d} \bar{\varepsilon}
$$

$\bar{\varepsilon}_{\mathrm{f}}$ is the total equivalent strain at the end of forming process.

The magnitude of $C$ should not exceed $C_{\max }$ (critical damage value) for the non-occurrence of any damage. When the $C$ value is compared to $C_{\max }$, material damage risk is assessed during the process. Equation (1) should be turned into a separate expression that is convenient for FE code for the purpose of calculating the $\mathrm{C}$ value with FE simulation, Equation (2):

$$
C=\int_{0}^{\bar{\varepsilon}_{\mathrm{f}}} \frac{\sigma_{\mathrm{T}}}{\bar{\sigma}} \frac{\mathrm{d} \bar{\varepsilon}}{\mathrm{d} t}=\int_{0}^{t_{\mathrm{f}}} \frac{\sigma_{\mathrm{T}}}{\bar{\sigma}} \dot{\bar{\varepsilon}} \mathrm{d} t \cong \sum_{0}^{t_{\mathrm{f}}} \frac{\sigma_{\mathrm{T}} \dot{\bar{\varepsilon}} \Delta t}{\bar{\sigma}}
$$

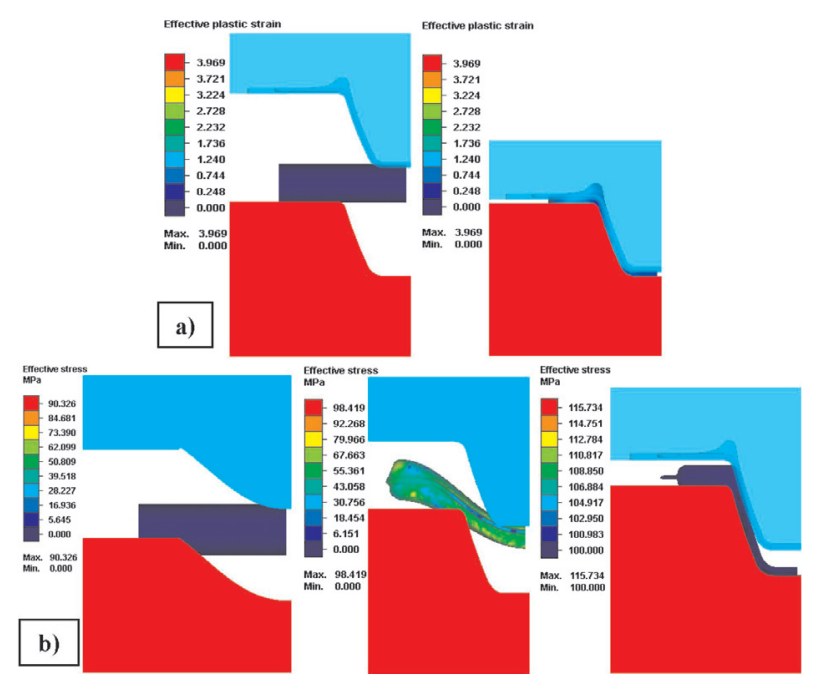

Figure 3: Schematic view of simulations: a) simulation 1 and simulation 2, b) simulation 3 where $\dot{\bar{\varepsilon}}$ is the equivalent strain rate as Equation (1) calculated from the individual principal strain-rate components, and $\Delta t$ is the variable time increment used in the FE analysis. Cockroft Latham constant $\left(C_{\max }\right)$ is dependent on the same material parameters on which the forming limits are dependent. While the metallurgical properties such as microstructure, alloy constant, grain dimension and particle structure and non-metallic inclusion content have a little impact on the strength and hardness, they have a significant impact for the critical damage value. ${ }^{15}$ In order to predict the occurrence of surface fracture, the value of the Cockcroft-Latham equation expressed by means of Equation (1) is calculated at the integration point inside the elements.

A symmetrical half of the piece has been taken for the purpose of shortening the solution period in all the simulation works due to the fact that the TH34 bottom clamp aimed to be attained in hot-forging simulations has a symmetrical geometry. The workpiece attained at the end of each forging stage has been used as the input of the next stage, together with all the deformation properties. In simulation 1 and simulation 2 , the raw material with the dimensions $\varnothing 50 \times 286 \mathrm{~mm}$ has been forged at a single stage, as shown in Figure 3a.

In simulation 3 , the section designs of the forged piece were conducted within the direction of the principle of volume stability, die designs convenient for the section designs have been made and the forging process has been realized in three stages, as shown in Figure $\mathbf{3 b}$. The optimized parameters of simulation 3 were used in the pilot production without any modification and the bottom clamp was manufactured, as shown in Figure 4.

In order to observe the forging flowlines in the process of deformation of the workpiece, the specimens were prepared by using a wire erosion machine which were manufactured by the hot-forging method. In accordance with the ASTM E381-01 standard, $50 \% \mathrm{HCl}$ and $50 \%$ purified watered etchant was prepared. The specimens were macro-etched for $15 \mathrm{~min}$ at $80{ }^{\circ} \mathrm{C}$ in a temperature-controlled heating table.

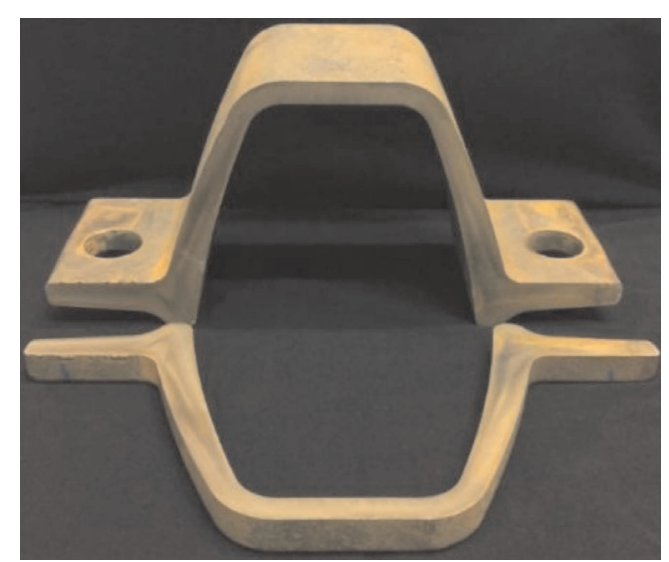

Figure 4: TH34 bottom clamp after pilot production 


\section{RESULTS}

Analyses have been realized for simulation 1 fictionalized within the direction of the process parameters shown in Table 3 and the effective stress, effective strain and critical damage value results belong to simulation 1 are shown in Figure 5. As shown in Figure 5, the unfilled zones of the die as a result of the forging of the raw material with the dimensions $\varnothing 50 \times 286 \mathrm{~mm}$ at single stage and the zones with the critical damage value regarding Cockroft-Latham criterion in Figure 5.

Because it is clear that the die has not been filled within the direction of the results attained in simulation 1, the raw-material dimensions were increased as $\varnothing 50 \times 292 \mathrm{~mm}$ and simulation 2 has been carried out.

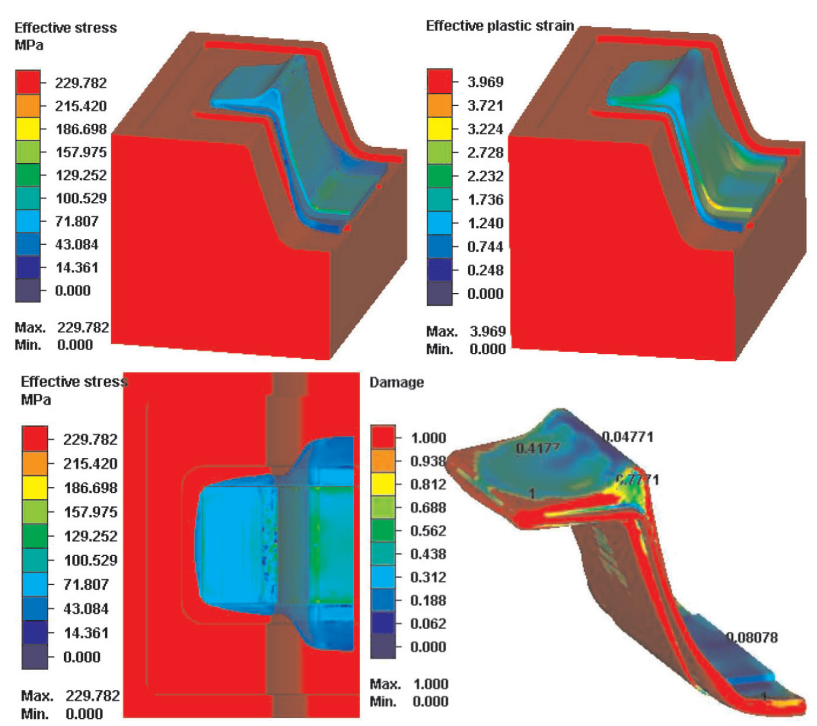

Figure 5: Effective stress, plastic strain and critical damage value distribution in simulation 1
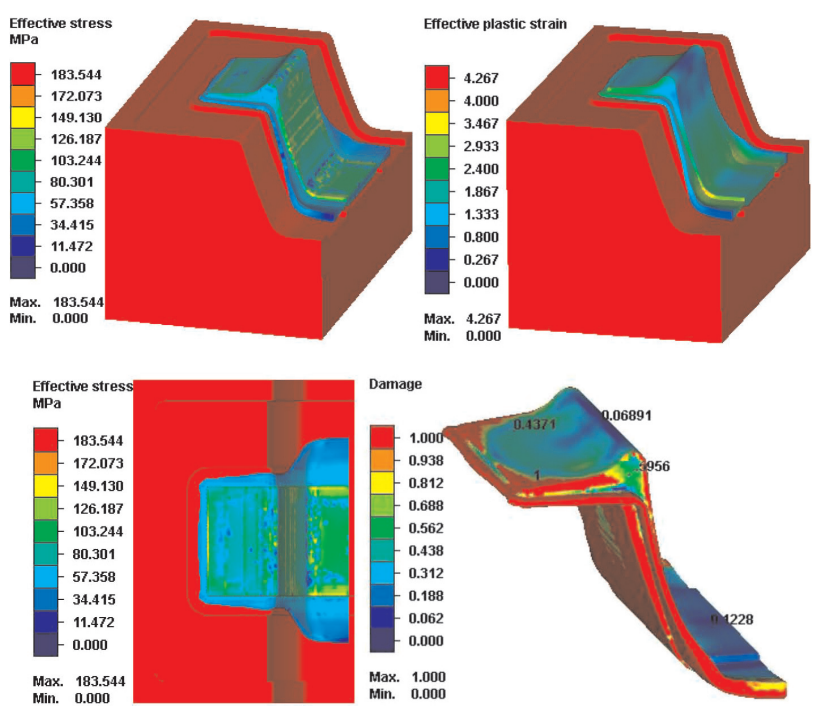

Figure 6: Effective stress, effective plastic strain and critical damage value distribution in simulation 2

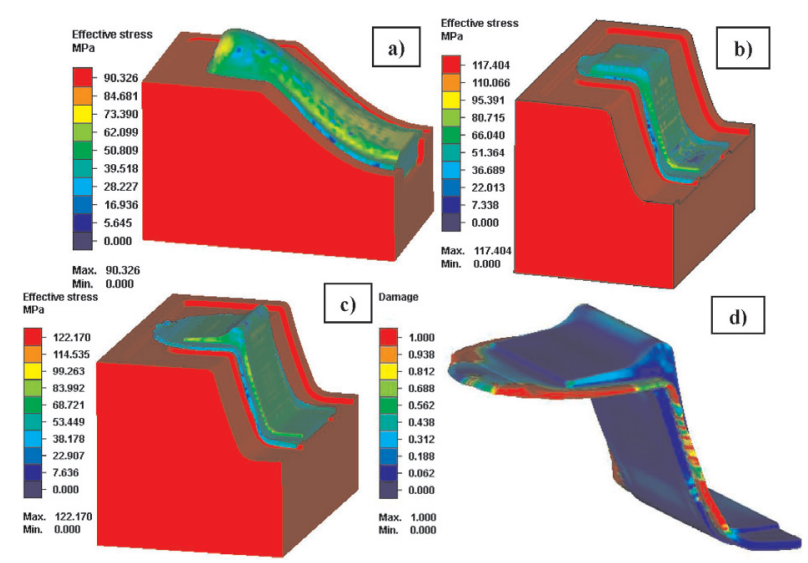

Figure 7: Effective stress and critical damage values: a) first preforming stage, b) second pre-forming stage, c) finisher forging stage

The effective stress, effective strain and critical damage value results attained as a result of simulation 2 are shown in Figure 6.

It is clear that the die has been completely filled. as shown in Figure 6, in the forging process realized with the raw material with the dimensions $\varnothing 50 \times 292 \mathrm{~mm}$. The zones having critical damage value regarding Cockroft-Latham criterion are shown in Figure 6.

The flow lines have been added to the material section during the forging process in simulation 2 and the final situation of the material flow attained as a result of the forging process at single stage is shown in Figure 8.

Analyses were carried out for simulation 3 fictionalized as forging of the raw material with the dimensions $\varnothing 50 \times 286 \mathrm{~mm}$ in three stages within the direction of the

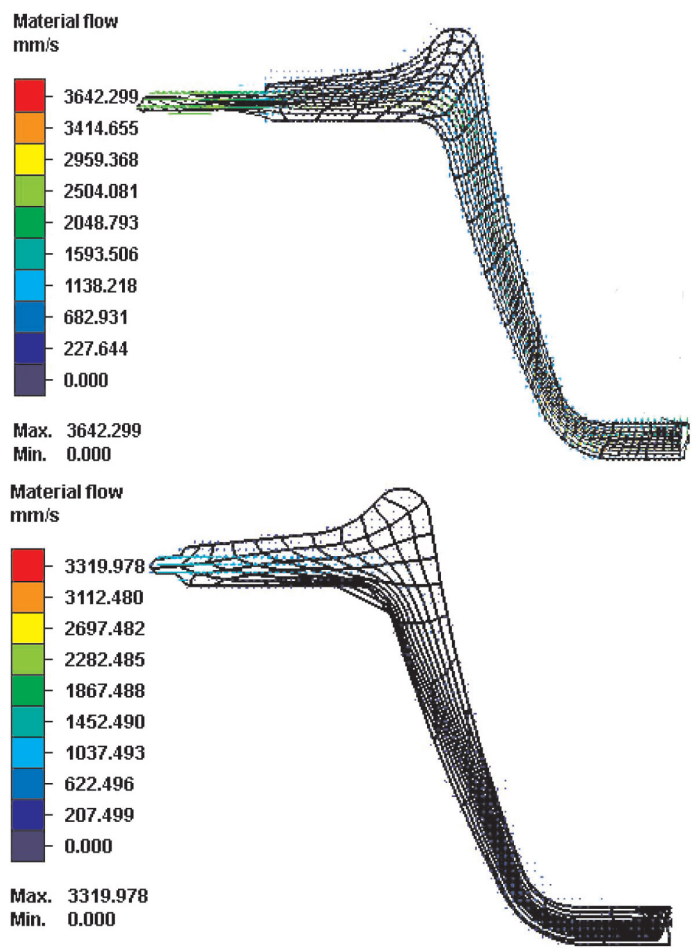

Figure 8: Material flow and flowlines results in simulation 3 and simulation 2 


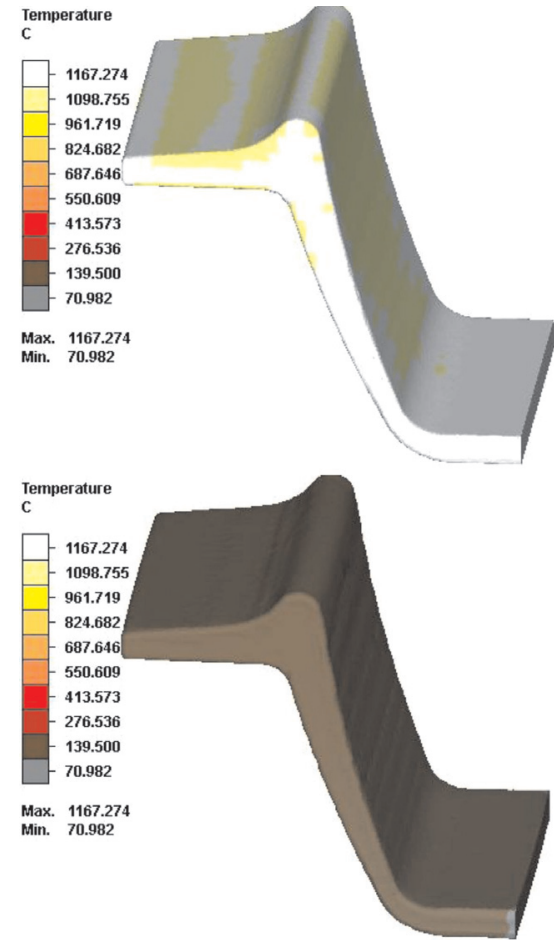

Figure 9: a) Clamp temperature distribution after forging, b) clamp temperature distribution after cooling

process parameters shown in Table 3 and the results belonging to simulation 3 are shown in Figure 7.

It was observed that the die has been completely filled, as shown in Figure 7, in the forging process realized with the raw material with the dimensions $\varnothing 50 \times 286 \mathrm{~mm}$. The zones having critical damage value regarding the Cockroft-Latham criterion are shown in Figure 7d.

Flow lines were added to the material section during the forging processes in simulation 2 and simulation 3 and the final situation of the material flow attained as a result of the forging process is shown in Figure 8.
The forged piece attained at the end of simulation 3 has been taken to the trimming die for the purpose of taking its flashes and this process has been carried out. The TH34 bottom clamp with high temperature shown in Figure 9a was cooled down in air with the ambient temperature of $50{ }^{\circ} \mathrm{C}$ and the distribution of the surface temperatures regarding the clamp attained at the end of the cooling of $30 \mathrm{~min}$ is shown in Figure 9.

The force and energy data regarding the hot-forging simulations are shown in Table 4.

Table 4: Force and energy data regarding the hot-forging simulations

\begin{tabular}{|c|c|c|c|c|c|}
\hline \multirow{2}{*}{$\begin{array}{c}\text { Simula- } \\
\text { tion } \\
\text { name }\end{array}$} & \multirow[b]{2}{*}{ Stage name } & \multirow{2}{*}{$\begin{array}{l}\text { Stroke } \\
(\mathrm{mm})\end{array}$} & \multicolumn{2}{|c|}{ Force $(\mathrm{kN})$} & \multirow{2}{*}{$\begin{array}{c}\text { Energy } \\
(\mathrm{kJ})\end{array}$} \\
\hline & & & Bottom die & Top die & \\
\hline $\begin{array}{l}\text { Simula- } \\
\text { tion } 1\end{array}$ & Finisher forging & 140.4 & -13449.8 & 14081.4 & 65.6 \\
\hline $\begin{array}{l}\text { Simula- } \\
\text { tion } 2 \\
\end{array}$ & Finisher forging & 140.4 & -18963.5 & 19299.9 & 71.3 \\
\hline \multirow{3}{*}{$\begin{array}{l}\text { Simula- } \\
\text { tion } 3\end{array}$} & $\begin{array}{l}\text { First pre- } \\
\text { forming }\end{array}$ & 61.52 & -2208.5 & 1965.7 & 14.6 \\
\hline & $\begin{array}{l}\begin{array}{c}\text { Second pre- } \\
\text { forming }\end{array} \\
\end{array}$ & 91.97 & -11743.3 & 12033.8 & 34.3 \\
\hline & Finisher forging & 26.3 & -15270.1 & 15216.2 & 27.6 \\
\hline
\end{tabular}

As shown in Figure 4, the TH34 bottom clamp was produced by using the hot-forging process and the macro-etching sample was obtained according to the standards. The regions where the material flowlines are observed and the flowlines obtained as a result of the macroscopic examinations are shown in Figure 10.

\section{DISCUSSION}

Section and die designs have been completed for the hot-die forging processes planned to be carried out in single and multiple stages and realized upon the final product measurements of the TH34 ground support bottom clamp. According to the performed designs, the
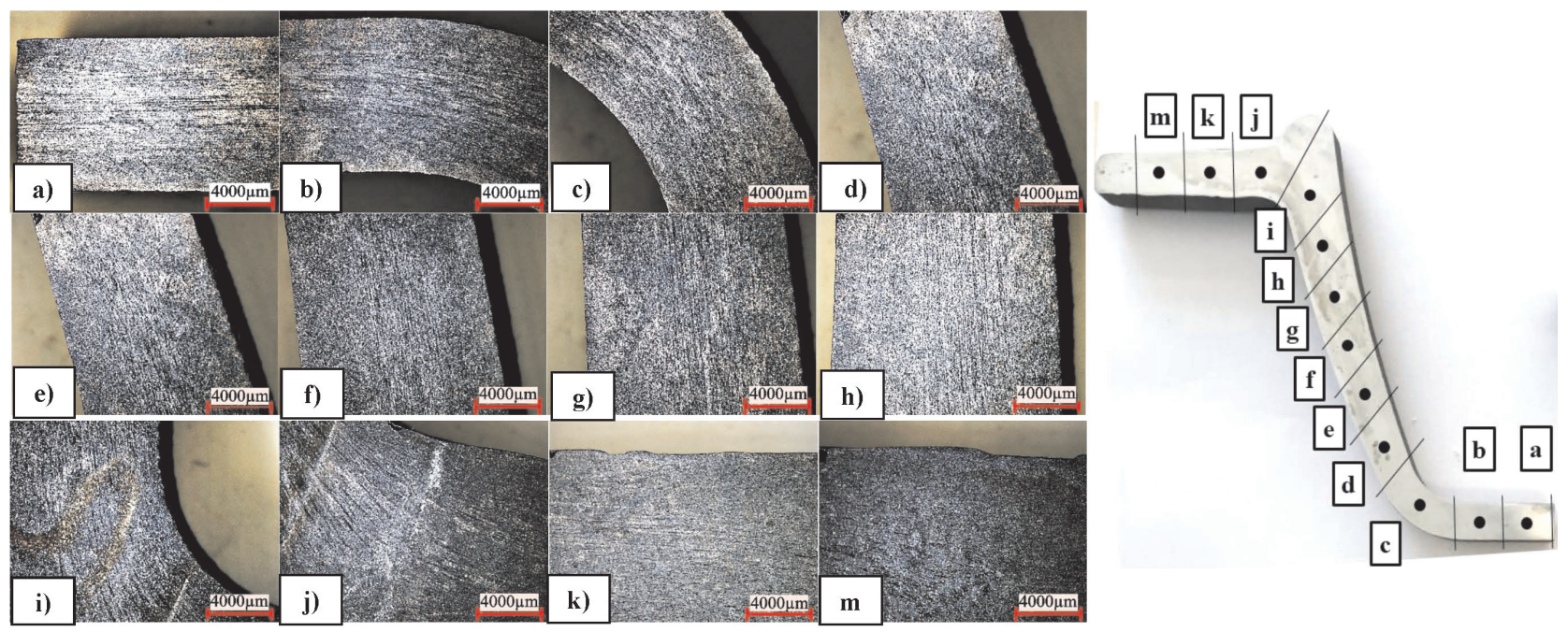

Figure 10: Macroscopic flowlines examination after the macro-etching process 
installation of the simulation was completed and the following results were obtained:

Firstly, the flash design has been carried out within the direction of the forged piece design made according to the volume calculation principles of hot forging die making and it has been determined that the flash dimensions should be $4 \mathrm{~mm} \times 16 \mathrm{~mm}$ according to the calculation made according to Voigtlander, Doege and Awiszus and the volume of the raw material should be $561,560 \mathrm{~mm}^{3}$ within the direction of the fact that the shrinkage allowance peculiar to steel material should also be given. ${ }^{19,20}$

It has been determined that the shrinkage allowance added to the piece in the forging design has been correctly assigned, as seen in the measurements as a result of cooling the workpiece in air at the end of hotforging process. ${ }^{25}$

When simulation 1 which includes the forging of the workpiece with the dimensions of $\varnothing 50 \times 286 \mathrm{~mm}$ in single stage is examined; it has been determined that $13449.8 \mathrm{kN}$ forging force has an impact on the bottom die and $14081.4 \mathrm{kN}$ forging force has an impact on the upper die. It has been determined that $65.6 \mathrm{~kJ}$ is needed for the production of the TH34 bottom clamp with hot die forging method from the workpiece with the dimensions of $\varnothing 50 \times 286 \mathrm{~mm}$. As can be seen in Figure 5, as a result of the forging simulation, it has been observed that the flash formation increases in the base zone of the material due to not being able to direct the material flow and for this reason, the die is not filled. The critical damage value of this piece forged in single stage and the zones with the probability of damage formation have been examined. It has been determined that the Cockroft-Latham critical damage value reached 1 and the zones with the probability of damage formation include the majority of the material.

The volume of the raw material has been increased by $11781 \mathrm{~mm}^{3}$ for the purpose of being able to terminate the deficient filling problem of the die in simulation 1 and simulation 2 has been realized. When the results of simulation 2 has been examined; it has been determined that $18963.5 \mathrm{kN}$ forging force has an impact on the bottom die with an increase of $41 \%$ and $19299.9 \mathrm{kN}$ forging force has an impact on the upper die with an increase of $37 \%$. It has been determined that $71.3 \mathrm{~kJ}$ is needed for the production of the TH34 bottom clamp with the hot die forging method from the workpiece with the dimensions of $\varnothing 50 \times 292 \mathrm{~mm}$. As can be seen in Figure 6; as a result of the forging simulation in which the volume of the work piece has been increased by $11781 \mathrm{~mm}^{3}$, it has been observed that the die has been completely filled. The critical damage value of this piece forged in single stage and the zones with the probability of damage formation have been examined. It has been determined that Cockroft-Latham critical damage value reached 1 and the zones with the probability of damage formation include the majority of the material.
When simulation 3 , which includes the forging of the workpiece with the dimensions of $\varnothing 50 \times 286 \mathrm{~mm}$ in 3 stages, was examined, it was observed that the final stage die has been completely filled, flash formation has been distributed in a more homogenous way when compared to simulation 1 and simulation 2 . When the forces having impact on the dies belonging to 3 -stage forging simulation have been examined; it has been determined that $15270.1 \mathrm{kN}$ forging force has an impact on the bottom die and 15216.2 $\mathrm{kN}$ forging force has an impact on the upper die at the final forming stage in which the greatest forces occur. It is shown in Table 4 that the maximum energy requirement is $34.3 \mathrm{~kJ}$ in the 3 -stage forging process for the production of TH34 bottom clamp. When the critical damage value of this piece forged in three stages and the zones with the probability of damage formation have been examined; it has been determined that Cockroft-Latham critical damage value has reached maximum 1 in the flash zone as shown in Figure 7c and the maximum critical value is 0.5 in the areas covering the clamp. As a result of the attained data, it is expressed that the amount of Cockroft-Latham criterion is within the range $0.7-0.8$. The flashes of the forged piece have been taken in the trimming die following the realization of the hot die forging process of TH34 bottom clamp. The forged piece has been cooled for $30 \mathrm{~min}$ in the ambient temperature of $50{ }^{\circ} \mathrm{C}$. At the end of $30 \mathrm{~min}$, it has been determined that the temperature is $80^{\circ} \mathrm{C}$ in the maximum zone of the surface temperature as shown in Figure 9 in which the distribution of the surface temperatures of the forged piece is given. It has been observed that the zones in which critical damage may occur are not existent in the clamp examined at the end of the trimming and cooling process.

When the formation of the material flow lines belonging to the products attained as a result of simulation 2 and simulation 3 have been examined, it was clear that the material flow lines attained in simulation 2 are not in accordance with the final product geometry. The attainment of the flow lines in accordance with the product geometry has an importance in the improvement of the strength and toughness of the product attained with forging. ${ }^{6}$ When the material flow attained in simulation 3 has been examined, it is seen that the material flow in accordance with the final product geometry has been realized. It has been determined that when the flow lines at the end of the macro-etching processes of the samples taken from the pilot production performed in the direction of the parameters obtained in Simulation 3 are examined, similar material flow lines are obtained with simulation 3 .

\section{CONCLUSIONS}

It has been determined that subjecting the raw material belonging to the piece to be produced with mould hot forging method to the pre-forming stage is an 
important factor in attaining the minimum forging forces and the minimum raw-material wastes and with the impact on the complete filling of the die.

It is seen that in the hot-forging process, determining the forging steps in such a way that the total forging force required for the forging operation is evenly as distributed as possible is the most suitable method for forging operations.

The direction of the material flow in the forging in accordance with the final product geometry both improves the mechanical properties of the final product and it also decreases the energy needs during the forging process.

While the increase in temperature decreases $C$, which is the strength constant, it increases the strain-rate sensitivity $(m)$. Because the forming process is applied at high temperatures, it is necessary to decrease the deformation speed as much as possible. The attainment of products is possible with a press or hammers with low capacity by increasing the forging stages and decreasing the energy needs per stages in the conditions in which the infrastructure of the establishment is insufficient in the attainment of the pieces planned to be produced in the hot-forging industry.

\section{REFERENCES}

${ }^{1}$ C. Wang, Y. Wen, F. Han, Analysis on investment environment of mining industry in China, Procedia Environmental Sciences, 12 (2012), 243-251, doi:10.1016/j.proenv.2012.01.273

${ }^{2}$ G. Wu, W. Yu, J. Zhang, Y. Ning, Control mechanism and support technology of soft coal roadway in the fully mechanized mining work face, Geo-Resources Environment and Engineering (GREE), 2 (2017) 211-217, doi:10.15273/gree.2017.02.038

${ }^{3}$ S. C. Li, Q. Wang, H. T. Wang, B. Jiang, D. C. Wang, B. Zhang, Y Li, G. Q. Ruan, Model test study on surrounding rock deformation and failure mechanisms of deep roadways with thick top coal, Tunnelling and Underground Space Technology, 47 (2015) 52-63, doi:10.1016/ j.tust.2014.12.013

${ }^{4}$ X. Tan, W. Chen, H. Liu, A. H. C. Chan, H. Tian, X. Meng, F. Wang, $\mathrm{X}$. Deng, A combined supporting system based on foamed concrete and U-shaped steel for underground coal mine roadways undergoing large deformations, Tunnelling and Underground Space Technology, 68 (2017) 196-210, doi:10.1016/j.tust.2017.05.023

${ }^{5}$ D. Demirci, E. Ozkan, M. E. Ercin, N. Şahan, O. Çulha, Simulation aided prototype production design of hot rolled mining gallery support Profile, The International Conference on Material Science and Technology (IMSTEC) in Cappadocia, 2016

${ }^{6}$ M. G. Rathi, N. A. Jakhade, An Overview of forging processes with their defects, International Journal of Scientific and Research Publications, 4 (2014) 6, doi:16.0415/IJARIIE-6948

${ }^{7}$ R. Maarefdoust, M. Maarefdoust, Analysis of finite volume of forging process of connecting rod, Advanced Materials Research 341
(2012), Trans. Tech. Publications, 313-317, doi:10.4028/ www.scientific.net/AMR.341-342.313

${ }^{8}$ V. V. Kukhar, R. S. Nikolenko, V. A. Burko, Analysis of die-forging variants of geometrically complex forgings in Deform 3D package, Metallurgical \& Mining Industry, 1, 2016

${ }^{9}$ R. Sowerby, N. Chandrasekaran, The prediction of damage accumulation when upsetting AISI 1045 steel specimens, based on McClintock's model, Materials Science and Engineering, 79 (1986) 1, 27-35, doi:10.1016/0025-5416(86)90383-6

${ }^{10}$ Y. F. Xia, G. Z. Quan, Z. H. O. U. Jie, Effects of temperature and strain rate on critical damage value of AZ80 magnesium alloy, Transactions of Nonferrous Metals Society of China, 20 (2010), 580-583, doi:10.1016/S1003-6326(10)60542-0

${ }^{11}$ H. Grass, C. Krempaszky, T. Reip, E. Werner, 3-D Simulation of hot forming and microstructure evolution, Computational Materials Science, 28 (2003) 3, 469-477, doi:10.1016/j.commatsci.2003. 06.003

${ }^{12}$ A. L. I. Moraes, O. Balancin, Numerical simulation of hot closed die forging of a low carbon steel coupled with microstructure evolution, Materials Research 18 (2015), 1, 92-97, doi:10.1590/1516-1439. 273114

${ }^{13}$ A. Gaikwad, S. Kirwai, P. Koley, G. Balachandran, R. Singh, Theoretical study on cold open die forging process optimization for multipass workability, MATEC Web of Conferences, 80, (2016), 13002, doi: $10.1051 /$ matecconf/20168013002

${ }^{14}$ I. M. Pereira, G. Rubim, O. Acselrad, P. R. Cetlin, Comparison of the experimental and the numerically predicted mechanical damage in the sheet forming of steel, Journal of Materials Processing Technology, 203 (2008) 1, 13-18, doi:10.1016/j.jmatprotec.2007.09.083

${ }^{15}$ D. C. Ko, B. M. Kim, J. C. Choi, Prediction of surface-fracture initiation in the axisymmetric extrusion and simple upsetting of an aluminum alloy. Journal of Materials Processing Technology, 62 (1996), 1-3, 166-174, doi:10.1016/0924-0136(95)02200-7

${ }^{16}$ DIN 21530-3: 2003, Mine support, Part 3, Requirements, German Institute for Standardization, Berlin

${ }^{17}$ DIN 21530-2: 2003, Mine support, Part 2, Dimensions, designation and statical values, German Institute for Standardization, Berlin

${ }^{18}$ G. Zhao, E. D. Wright, R. V. Grandhi, Forging preform design with shape complexity control in simulating backward deformation, International Journal of Machine Tools and Manufacture, 35 (1995) 9, 1225-1239, doi:10.1016/0890-6955(94)00117-3

${ }^{19}$ E. Sleeckx, J. P. Kruth, Review of flash design rules for closed-die forgings. Journal of Materials Processing Technology, 31 (1992), 1-2, 119-134, doi:10.1016/0924-0136(92)90013-I

${ }^{20}$ G. Boothroyd, P. Dewhurst, W. A. Knight, Product design for manufactuing and assembly, CRC press, (2010), doi:10.1002/ 0471777463.ch1

${ }^{21}$ G. E. Dieter, H. A. Kuhn, S. L. Semiatin, Handbook of workability and process design, ASM International, 2006

${ }^{22}$ T. Altan, G. Ngaile, G. Shen, Cold and hot forging: fundamentals and applications, Vol. 1, ASM International, 2005

${ }^{23}$ R. Crowson, Product design and factory development, Handbook of Manufacturing Engineering, 2005, 92-115

${ }^{24}$ M. T. Mang, W. Dresel, Lubricants and lubrication, 2007, 668-684, doi:10.1002/9783527610341

${ }^{25}$ D. A. Madsen, D. P. Madsen, Engineering drawing and design, Nelson Education, 2016, 322-326 